\title{
ANALISIS SURVIVAL DENGAN MENGGUNAKAN METODE KAPLAN MEIER PADA PENDERITA PENYAKIT DEMAM BERDARAH DENGUE (DBD)
}

\author{
Adnan Sauddin, M. Ichsan Nawawi, Muhalki \\ (Universitas Islam Negeri Alauddin Makassar)
}

\begin{abstract}
The Kaplan Meier method is one of the methods in survival analysis that is used to find out how big the chances of survival of a person suffering from a certain disease. The Kaplan Meier method calculates the patient's life by providing a definite survival proportion. The purpose of this study was to determine the relationship between age and length of treatment and patient status. The life chances of DHF patients using the Kaplan Meier method at the Lasinrang District Hospital. Pinrang. The results showed that there was no relationship between age and length of treatment as well as the status of DHF patients in Lasinrang Hospital Kab. Pinrang. The conclusion of this study is that the chance of survival of DHF patients before a patient dies is $100 \%$. However, the chance of patient survival after 1 patient died during the observation was $99.1 \%$. It is recommended that clinical monitoring should always be carried out, to predict the correct diagnosis of Dengue Virus Infection. And sero-epidemiological studies should continue to be carried out in many island capitals in Indonesia.
\end{abstract}

Keywors: Survival Analysis; Kaplan meier; DBD.

\begin{abstract}
Abstrak
Metode Kaplan Meier adalah salah satu metode dalam analisis survival yang digunakan untuk mengetahui seberapa besar peluang bertahan hidup seseorang yang menderita suatu penyakit tertentu. Metode Kaplan meier menghitung kelangsungan hidup penderita dengan memberikan proporsi survival yang pasti. Tujuan penelitian ini untuk mengetahui hubungan antara usia terhadap lama perawatan dan status pasien. Peluang kelangsungan hidup pasien DBD menggunakan metode Kaplan meier di RSUD Lasinrang Kab. Pinrang. Hasil penelitian menunjukkan bahwa tidak terdapat hubungan usia dan lama perawatan serta status pasien DBD di RSUD Lasinrang Kab. Pinrang. Kesimpulan dari penelitian ini adalah peluang ketahanan hidup pasien penyakit $D B D$ sebelum ada pasien yang meninggal adalah $100 \%$. Namun, peluang ketahanan hidup pasien setelah terdapat 1 pasien yang meninggal selama pengamatan yaitu sebesar 99,1\%. Disarankan pemantauan manifestasi klinis harus selalu dilakukan, untuk memprediksi diagnosis Infeksi Virus Dengue yang tepat. Dan studi sero-epidemiologi harus terus dilakukan di banyak ibu kota pulau di Indonesia.
\end{abstract}

Kata Kunci: Analisis survival; Kaplan meier; DBD

\section{PENDAHULUAN}

Demam berdarah merupakan salah satu penyakit tropis yang paling sering menyerang manusia. Demam berdarah telah menjadi masalah internasional utama dalam kesehatan masyarakat dalam beberapa dekade terakhir. Organisasi Kesehatan Dunia (WHO) memperkirakan bahwa sekitar 2,5-3 miliar orang saat ini tinggal di zona penularan demam berdarah. Dengue adalah penyakit demam akut yang dipicu oleh infeksi virus dengue (DENV). DENV adalah flavivirus RNA untai positif tunggal, anggota keluarga Flaviviridae. Virus ini memiliki empat serotipe utama (DENV-1, DENV-2, DENV-3, dan DENV-4). Manusia 
terinfeksi DBD melalui gigitan nyamuk Aedes betina pembawa DENV, termasuk Aedes albopictus dan Aedes aegypti. Infeksi selanjutnya dengan serotipe khas DENV telah dikaitkan dengan peningkatan risiko komplikasi parah. ${ }^{1}$

DBD menjadi penyakit langganan disetiap tahunnya di Indonesia. Di Provinsi Sulawesi Selatan sendiri telah terhitung 2.122 kasus DBD. Kecederungan meningkatnya penyakit ini disebabkan beberapa faktor seperti lingkungan yang kotor, musim penghujan yang menyebabkan banyak genangan air, countainer, dan musim pancaroba yang mengakibatkan udara menjadi lembab sehingga menyebabkan populasi nyamuk meningkat khususnya nyamuk Aedes aegypti yang menyebarkan virus dengue sebagai penyebab DBD. ${ }^{2}$ Provinsi Sulawesi Selatan masuk dalam 10 besar dengan jumlah kasus DBD terbanyak di Indonesia menurut data direktorat pengendalian penyakit tular vector dan zoonosis Kementerian Kesehatan.

Penderita penyakit DBD melakukan upaya pengobatan untuk tetap bertahan, seperti halnya mengkonsumsi obat penurun demam, mengkonsumsi vitamin agar daya imun tubuh menjadi lebih kuat, dan tidak mengkonsumsi obat nyeri karena akan memperparah kondisi. Penyakit Demam Berdarah Dengue merupakan salah satu jenis penyakit menular yang sangat berbahaya, hingga dapat menimbulkan kematian dalam waktu singkat dan melewati beberapa fase. ${ }^{3}$

Ketika seseorang dinyatakan menderita suatu penyakit hanya akan ada 2 kemungkinan yang biasa terjadi yaitu sembuh (hidup) dan meninggal dunia. Untuk dapat mengtahui peluang apakah seseorang yang telah menderita suatu penyakit dapat tetap bertahan atau tidak, dikenal istilah dalam bidang statistik yaitu analisis survival, dimana akan dilakukan analisis data berupa waktu tahan hidup dan varibel yang dapat mempengaruhi terhadap waktu tahan tersesebut, dimana waktu dapat berupa bulan, hari, jam maupun menit yang diukur sejak awal pengamatan sampai munculnya suatu kejadian. Adapun metode yang memiliki kesimanbungan dengan analisis survival, dimana metode tersebut dapat digunakan untuk menangani data tak lengkap dalam melakukan analisis data survival dari fungsi tahan hidup, yaitu metode Kaplan Meier.

Metode Kaplan-Meier merupakan metode yang sering digunakan oleh peneliti seperti halnya Gayanti (2016) yang kesimpulannya dalam menghitung peluang kelangsungan hidup penderita penyakit jantung ditahun 2014 sebesar 92,3\% dan di tahun 2015 sebesar 93,4\% ini menandakan bahwa peluang berthan hidup yang dimiliki besar, Rahmat Hidayat (2016) yang melakukan perbandingan dengan menggunakan Metode Kaplan Meier dan Life Table untuk data tersensor yang menghasilkan kesimpulan bahwa penggunaan Metode Kaplan Meier lebih baik dari pada Life Table karena Metode Kaplan Meier memberikan proporsi survival yang pasti karena menggunakan waktu survival secara tepat bukan berdasarkan kelas interval. ${ }^{4,5}$ 
Metode Kaplan Meier ini juga dapat digunakan untuk sampel yang kecil, sedang dan besar. Sehinggal hal ini melatar belakangi penulis tertarik untuk mengambil tema penelitian "Analisis Survival dengan Menggunakan Metode Kaplan-Meier pada Penderita Penyakit DBD Di Rumah Sakit Umum Lasinrang Kab. Pinrang".

Dalam penelitian ini juga menguji hipotesis komparatif dua sampel independen berarti menguji signifikansi perbedaan nilai dua sampel yang tidak berpasangan. Sampel independen biasanya digunakan dalam penelitian yang menggunakan pendekatan penelitian survey, sedangkan sampel berpasangan banyak digunakan dalam penelitian eksperimen. Statistik nonparametrik yang digunakan untuk menguji hipotesis komparatif dua sampel independen bila memiliki data dengan bentuk nominal yaitu salah satunya Chi Kuadrat.

Rumus-rumus sederhana untuk menghitung $x^{2}$ yang hanya melibatkan frekuensifrekuensi pengamatan dapat diturunkan, seperti untuk tabel kontengensi $3 \times 2$

$$
x^{2}=\sum \frac{\left(O_{i}-E_{i}\right)^{2}}{E_{i}}
$$

Analisis survival adalah teknik statistik yang digunakan untuk menganalisis data yang bertujuan untuk mengetahui hasil dari variable yang mempengaruhi suatu awal kejadian sampai akhir kejadian, missal waktu yang dicatat dalam hari, minggu, bulan, atau tahun. Kejadiaan awal misalkan pasien terjangkit dan mendapat kejadian akhir berupa kematian, kekambuhan, atau kesembuhan pasien. Analisis survival merupakan kumpulan prosedur statistik untuk analisis data di mana variabel hasil yang menarik adalah waktu sampai suatu peristiwa terjadi. Karena menyensor nonobservasi dari peristiwa yang diminati setelah periode tindak lanjut, proporsi waktu kelangsungan hidup yang menarik sering kali tidak diketahui. ${ }^{6,7}$

Analisis survival (analisis kesintasan) adalah prosedur statistika untuk menganalisis data dengan waktu sampai terjadinya suatu peristiwa tertentu (time until an event occus) sebagai variable respons. 'Peristiwa tertentu' tersebut dalam analisis survival lazimnya disebut sebagai 'kegagalan' (failure), yang dapat berupa:

1. Kematian pada penderita penyakit fatal

2. Eksaserbasi ulang pada penderita penyakit kronis dengan remisi eksasebasi yang semula ada dalam fase remisi

3. Tindakan kriminal ulang oleh eks-narapidana yang sedang menjalani periode hukuman percobaan

4. Kekambuhan pada eks-pecandu narkotika sehabis menjalani rehabilitas. ${ }^{8}$

Perhitungan data menggunakan metode analisis ketahanan hidup disebut dengan data ketahanan hidup. Bentuk umumnya yaitu medeskripsikan proses waktu terjadinya suatu 
peristiwa. Bentuk utama dari stukturnya yaitu penyensoran. Suatu pengamatan ketahanan hidup memiliki batas waktu awal dan akhir pengamatan. Penyensoran terjadi ketika terdapat individu yang masih bertahan hidup setelah waktu pengamatan berakhir. Menurut Crowder terdapat 3 jenis penyensoran yaitu :

1. Left-censored

Pengamatan dikatakan Left-censored jika objek yang diteliti mengalami kejadian dibawah waktu pengamatan yang telah ditentukan.

\section{Right-censored}

Pengamatan dikatakan right-consored jika objek yang diteliti hilang, keluar, dan objek masih bertahan hidup setelah masa waktu pengamatan terakhir

3. Interval-censored

Pengamatan dikatakan interval-censored jika objek yang diteliti mengalami kejadian diantara interval waktu pengamatan tertentu

Fungsi survival adalah fungsi yang menyatakan peluang suatu individu dapat bertahan hidup hingga atau lebih dari waktu $t$ (mengalami kejadian sudah waktu $t$ ). ${ }^{9}$

Misal $T$ adalah peubah acak dan probabilitas hidup lebih dari waktu $t$, dimana $t>0$, maka fungsi survival didefinisikan sebagai :

$S(t)=P($ individu bertahan hidup lebih dari waktu $t)$

$=P(T \geq t)$

$S(t)=1-P($ individu gagal atau mati sebelum waktu $t)$

$=1-P(T \leq t)$

Misalkan $f$ fungsi kepekatan peluang, fungsi survival merupakan komplemen dari fungsi kumulatif $F$ dengan,

$$
\begin{aligned}
S(t) & =P(T \geq t) \\
& =1-F(t) \\
& =1-F(t)
\end{aligned}
$$

Karakteristik fungsi survival $S(t)$ antara lain adalah :

1. Tak membesar, fungsi survival $S(t)$ mengecil sejalan dengan bertambahnya nilai $t$.

2. Pada waktu $t=0, S(t)=S(0)=1$, yaitu pada awal studi belum ada subjek yang mengalami kegagalan atau $P(T>0)=1$

3. Pada waktu $t=\infty,(t)=(\infty)=0$, yaitu jika secara teoritis periode penelitian diperpanjang tanpa batas $(\infty)$, suatu saat tidak ada sampel yang survive.

Fungsi Hazard $h(t)$ yaitu fungsi yang menyatakan peluang seseorang mengalami risiko atau kejadian seperti kegagalan atau meninggal pada waktu $t$ dengan syarat bahwa seseorang itu telah bertahan hingga waktu $t$ didefinisikan : 


$$
\begin{aligned}
h(t) & =\lim _{\Delta t \rightarrow 0} \frac{P\left\{\begin{array}{c}
\text { seorang individu gagal pada interval waktu }(t, t+\Delta t) \\
\text { jika diketahui individu tersebut telah bertahan hingga } t
\end{array}\right\}}{\Delta t} \\
h(t) & =\lim _{\Delta t \rightarrow 0} \frac{P(t \leq T<t+\Delta t \mid T \geq t)}{\Delta t} \\
= & \lim _{\Delta t \rightarrow 0} \frac{P(t \leq T<(t+\Delta t) \cap(T \geq t)}{\Delta t \cdot P(T \geq t)} \\
= & \lim _{\Delta t \rightarrow 0} \frac{P(t \leq T<(t+\Delta t))}{\Delta t \cdot S(t)} \\
= & \frac{1}{S(t)} \cdot \lim _{\Delta t \rightarrow 0} \frac{P(t \leq T<(t+\Delta t))}{\Delta t} \\
= & \frac{f(t)}{S(t)}
\end{aligned}
$$

Analisis Kaplan Meier adalah metode yang paling umum digunakan untuk memperkirakan fungsi kelangsungan hidup atau kemungkinan mengalami suatu peristiwa setelah titik waktu tertentu. ${ }^{12}$ Metode Kaplan Meier sangat popular untuk analisis kelangsungan hidup yang paling cocok digunakan ketika ukuran sampel kecil. Analisis Kaplan Meier menggunakan asumsi sebagai berikut :

1. Subyek yang menarik diri dari penelitian secara rata-rata memiliki "nasib" kesudahan variabel hasil (peristiwa) yang sama dengan subyek yang bertahan selama pengamatan

2. Pengamatan antar subyek tidak mempengaruhi resiko (probabilitas) terjadinya variabel hasil (peristiwa), probabilitas peristiwa untuk berbagai jangka waktu tersebut dapat digambarkan sebagai kurva analisis survival. ${ }^{14}$

Estimasi Kaplan Meier juga merupakan perkembangan dari fungsi tahan hidup empiris. Fungsi tahan hidup empiris untuk seluruh data didefinisikan sebagai :

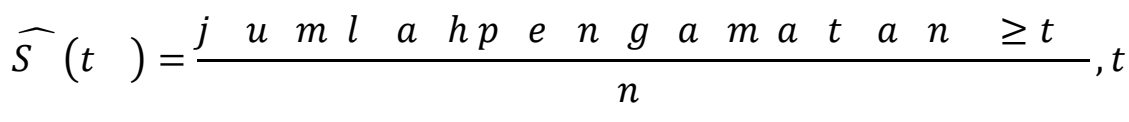$$
\geq 0
$$

Dimana $\widehat{S}(t \quad)=$ fungsi tahan hidup empiris ${ }^{15}$

\section{METODE PENELITIAN}

Jenis penelitian yang digunakan dalam penelitian ini yaitu penelitian terapan (applied research) untuk mengetahui probabilitas kelangsungan hidup pasien demam berdarah dengue. Data yang digunakan dalam penelitian ini adalah data sekunder. Dimana data diperoleh atau dikumpulkan peneliti dari sumber yang telah ada sebelumnya. Data yang digunakan pada penelitian ini adalah data pasien penderita penyakit DBD yang telah di 
rawat inap di RSUD Lasinrang Kab. Pinrang Tahun 2018-2019. Definisi variabel yang digunakan pada penelitian ini yaitu :

1. $X_{1}$ adalah umur pasien penderita penyakit DBD di RSUD Lasinrang Kab. Pinrang yang menjalani perawatan pada tahun 2018-2019.

2. $X_{2}$ adalah hari rawat pasien penderita penyakit DBD di RSUD Lasinrang Kab. Pinrang yang menjalani perawatan pada tahun 2018-2019.

3. $X_{3}$ adalah status pasien penderita penyakit DBD di RSUD Lasinrang Kab. Pinrang yang menjalani perawatan pada tahun 2018-2019.

4. $n_{i}$ adalah jumlah pasien yang menderita penyakit DBD di RSUD Lasinrang Kab. Pinrang selama menjalani perawatan pada tahun 2018 - 2019.

5. $d_{i}$ adalah pasien penderita penyakit DBD yang meninggal di RSUD Lasinrang Kab. Pinrang selama menjalani perawatan pada tahun 2018 - 2019.

Untuk mencapai tujuan dari penelitian ini, maka langkah - langkah yang dilakukan adalah sebagai berikut :

1. Mengumpulkan data jumlah pasien DBD.

2. Tabulasi data dan analisis chisquare untuk mengetahui hubungan antara umur terhadap hari rawat pasien kemudian hubungan antara umur terhadap status pasien.

3. Menghitung estimasi peluang kematian terhadap individu dengan menggunakan rumus :

$$
h(t)=\frac{d_{i}}{n_{i}}
$$

4. Menghitung estimasi fungsi ketahanan hidup terhadap masing - masing individu yang masuk dalam pengamatan dengan menggunakan rumus :

$$
\begin{aligned}
\hat{S}(t) & =\prod_{i: t}\left(1-\hat{h}\left(t_{i}\right)\right) \\
& =\prod_{i: t}\left(1-\frac{d_{i}}{n_{i}}\right)
\end{aligned}
$$

5. Melakukan penarikan kesimpulan terhadap hasil penelitian yang telah diperoleh berdasarkan tujuan dari penelitian. ${ }^{16}$

\section{HASIL PENELITIAN}

Adapun hasil penelitian dari data yang merupakan data penderita penyakit DBD diambil dari Rumah Sakit Umum Lasinrang Kab. Pinrang Tahun 2018-2019 adalah

\section{a. Statistika Deskriptif}


Tabel 1. Statistika Deskriptif Data Tahun 2018-2019

\begin{tabular}{cc}
\hline Variabel & Total \\
\hline Pasien yang meninggal karena $\operatorname{DBD}\left(d_{i}\right)$ & 1 \\
\hline Jumlah pasien penderita penyakit $\operatorname{DBD}\left(n_{i}\right)$ & 117 \\
\hline
\end{tabular}

\section{b. Hubungan antara umur terhadap hari rawat pasien}

Tabel 2. Jumlah pasien berdasarkan hari rawat dengan kategori umur

\begin{tabular}{ccc}
\hline \multirow{2}{*}{$X_{1}$} & \multicolumn{2}{c}{$X_{2}$ (hari) } \\
\cline { 2 - 3 } & $\leq 4$ & $>4$ \\
\hline Balita/anak-anak (0-11) & 6 & 22 \\
\hline Remaja/Dewasa (12-45) & 18 & 65 \\
\hline Lansia (46-65) & 3 & 3 \\
\hline
\end{tabular}

Berdasarkan dari tabel 2 menunjukkan bahwa terdapat 6 pasien balita/anakanak umur 0-11 tahun dengan hari rawat $\leq 4$ hari dan 22 pasien dengan hari rawat $>4$ hari. Sedangkan pada pasien remaja/dewasa yang berumur 12-45 tahun terdapat 18 pasien dengan hari rawat $\leq 4$ hari dan 65 pasien dengan hari rawat $>4$ hari. Selain itu pada pasien lansia pada umur 46-65 tahun terdapat 3 pasien dengan hari rawat $<4$ hari dan 3 pasien dengan hari rawat $>4$ hari.

Berdasarkan hasil analisis menggunakan chi-square menunjukkan bahwa tidak ada hubungan antara umur pasien penderita DBD dengan lama hari rawat pasien dilihat dari nilai $p$-value yang diperoleh yaitu 0.2748 dimana $>\alpha(0.05)$.

\section{c. Hubungan antara umur terhadap status pasien}

Tabel 3. Jumlah pasien berdasarkan status dengan kategori umur

\begin{tabular}{ccc}
\hline$X_{1}$ & \multicolumn{2}{c}{$X_{3}$} \\
\cline { 2 - 3 } Balita/anak-anak (0-11) & Sembuh & Meninggal \\
\hline Remaja/Dewasa (12-45) & 28 & 0 \\
\hline Lansia (46-65) & 82 & 1 \\
\hline
\end{tabular}

Berdasarkan dari tabel 3 menunjukkan bahwa terdapat 28 pasien balita/anakanak pada umur 0-11 tahun dengan status sembuh dan tidak terdapat pasien meninggal. Sedangkan pada pasien remaja/dewasa pada umur 12-45 tahun terdapat 82 pasien dengan status sembuh dan 1 pasien dengan status meninggal. Selain itu pada pasien lansia 46-65 tahun terdapat 6 pasien dengan status sembuh dan tidak terdapat pasien dengan status meninggal.

Berdasarkan hasil analisis menggunakan chi-square menunjukkan bahwa tidak ada hubungan antara umur pasien penderita DBD dengan status pasien dilihat dari nilai $\mathrm{p}$-value yang diperoleh yaitu 0.8134 dimana $>\alpha(0.05)$. 


\section{PEMBAHASAN}

\section{a. Menghitung estimasi peluang kematian individu $\widehat{h}(t)$}

Estimasi peluang kematian individu merupakan hasil bagi jumlah individu yang meninggal di bagi jumlah dari individu yang bertahan hidup di hitung berdasarkan lamamnya pasein dirawat. Untuk menghitung estimasi peluang kematian individu dengan menggunakan rumus:

$$
\hat{h}(t)=\frac{d_{i}}{n_{i}}
$$

Tabel 4. Estimasi peluang kematian individu pada tahun 2018-2019

\begin{tabular}{cccccccc}
\hline Hari ke & 1 & 2 & 3 & 4 & 5 & $\ldots$ & 18 \\
\hline$\hat{h}(t)$ & 0.0000 & 0.0086 & 0.0000 & 0.0000 & 0.0000 & $\ldots$ & 0.0000 \\
\hline
\end{tabular}

\section{kurva peluang kematian}

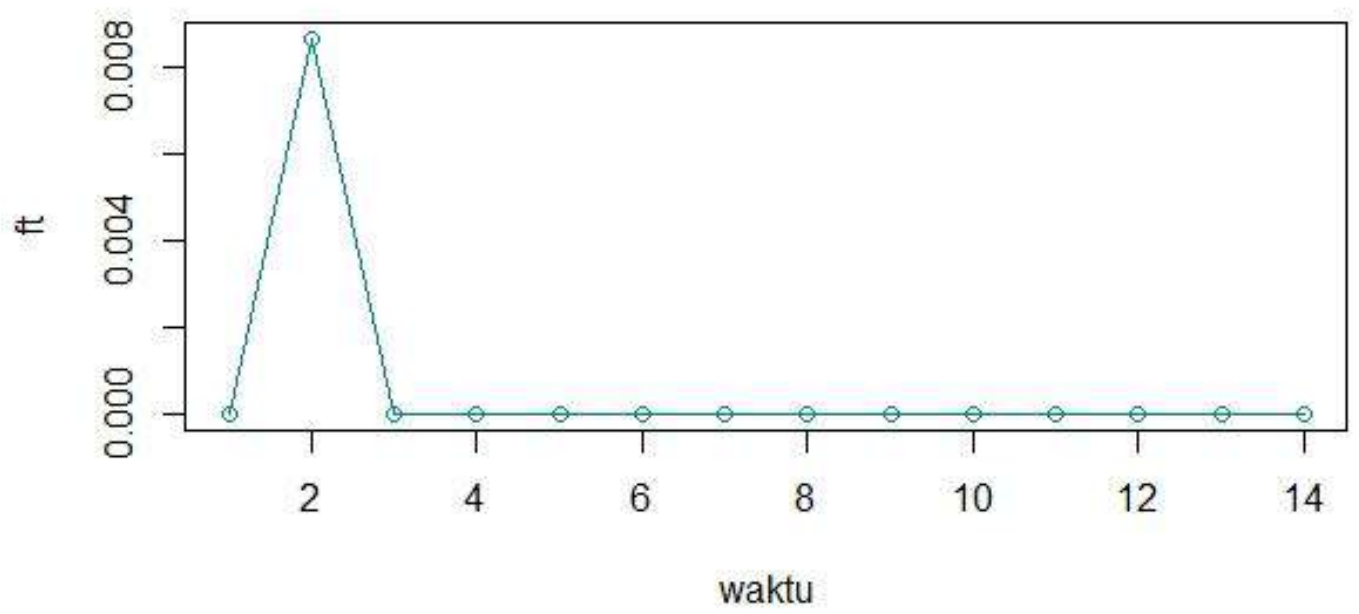

Grafik 1. Estimasi peluang kematian individu pada Tahun 2018-2019

Berdasarkan tabel 2 dan grafik 1 hasil perhitungan estimasi peluang kematian individu $\hat{h}(t)$ pada pasien DBD di tahun 2018-2019, dapat dilihat bahwa hanya pada waktu pengamatan hari ke 2 terdapat pasien yang meninggal dimana mempunyai hasil estimasi peluang kematian sebesar 0,0086 dan untuk waktu pengamatan selain hari ke 2 memiliki hasil estimasi peluang kematian yaitu sebesar 0 .

b. Estimasi fungsi ketahanan hidup individu (survival) $\widehat{S}(t)$ Tahun 2018-2019

Untuk mendapatkan hasil dari estimasi fungsi ketahan hidup tiap-tiap individu yang masuk dalam pengamatan yaitu selama Tahun 2018-2019 menggunakan rumus sebagai berikut:

$$
\hat{S}=\prod_{i: t} i \leq t\left(1-\frac{d_{i}}{n_{i}}\right), \text { untuk } 1 \leq t \leq 18
$$


Tabel 5. Estimasi fungsi ketahanan hidup individu tahun 2018-2019

\begin{tabular}{cccc}
\hline Hari ke & n.risk & n.event & survival \\
\hline 1 & 117 & 0 & 1.000 \\
2 & 116 & 1 & 0.991 \\
3 & 114 & 0 & 0.991 \\
4 & 111 & 0 & 0.991 \\
5 & 90 & 0 & 0.991 \\
6 & 58 & 0 & 0.991 \\
7 & 29 & 0 & 0.991 \\
$:$ & $:$ & $:$ & $:$ \\
11 & 6 & 0 & 0.991 \\
12 & 4 & 0 & 0.991 \\
13 & 3 & 0 & 0.991 \\
18 & 1 & 0 & 0.991 \\
\hline
\end{tabular}

Strata + All



Grafik 2. Estimasi fungsi ketahanan hidup individu Tahun 2018-2019

Pada tabel 5 terdapat $n$-risk yang merupakan banyaknya pasien yang beresiko, kemudian pada n-event pada hari ke 2 terdapat pasien DBD yang meninggal dengan jumlah pasien sebanyak 1 orang, sedangkan hari rawat lainnya tidak terdapat pasien DBD yang meninggal taksiran fungsi survival yang terdapat pada kolom "survival" dengan persentase terbesar belum terdapat pasien meninggal yaitu sebesar $100 \%$ dan yang terendah yaitu sebesar 99,1\% dengan melihat kolom "survival" tersebut dapat dilihat bahwa persentase peluang ketahan hidup pasien DBD tahun 2018-2019 mengalami penurunan setelah terdapat pasien meninggal. Sedangkan pada grafik 2 memuat perbandingann antara hari rawat (lama perawatan) pasien dan status pasien .

Berdasarkan data yang telah didapatkan di RSUD Lasinrang Kab. Pinrang dalam kurun waktu tahun 2018-2019 diketahui bahwa deskriptif data menunjukkan jumlah 
pasien penderita DBD sebanyak 117 dan terdapat 1 pasien yang meninggal. Dalam dunia kesehatan suatu individu dapat dengan mudah terjangkit virus dengue salah satunya dipengaruhi oleh faktor umur. Penyakit DBD dapat menyerang suatu individu baik itu anak-anak, dewasa maupun lansia. Selain itu waktu perawatan pada penderita DBD berbeda-beda tergantung dari tingkat keparahan yang dialami oleh pasien.

Berdasarkan hasil analisis chisquare tabel 2 diketahui tidak ada hubungan antara umur terhadap hari rawat pasien hal tersebut sejalan dengan penelitian yang dilakukan oleh Hasri Nopianto, dkk (2012) yang menunjukkan bahwa tidak ada hubungan antara umur terhadap lama rawat inap pasien DBD di RSUP DR Kariadi Semarang. ${ }^{18}$

Berdasarkan hasil analisis chisquare tabel 3 menunjukkan bahwa tidak ada hubungan antara umur terhadap status pasien berbeda dengan penelitian yang dilakukan oleh Mamluatul Hikmah dan Oktia Woro Kasmini $\mathrm{H}$ yang diketahui bahwa ada hubungan antara umur terhadap kejadian kematian pasien DBD. Selain itu pada penelitian ini juga disebutkan bahwa kejadian kematian pada pasien DBD cenderung terjadi pada pasien dengan kategori anak-anak dibandingkan dengan kategori remaja dan dewasa.

Pada perhitungan estimasi peluang kematian individu berdasarkan tabel 4 dengan menggunakan metode Kaplan-meier sebesar 0,0862\% setelah terdapat pasien yang meninggal pada hari rawat 2 hari. Sedangkan untuk hari rawat lainnya memiliki estimasi peluang kematian sebesar $0 \%$. Faktor yang secara signifikan mempengaruhi tingkat peningkatan kondisi klinis pasien DBD adalah usia dan trombosit. ${ }^{19}$

Selanjutnya perhitungan pada estimasi peluang fungsi ketahan hidup (survival) menggunakan metode Kaplan-meier pada tabel 5. Diketahui bahwa terdapat 117 pasien DBD yang beresiko selama hari rawat, dapat dilihat bahwa waktu perawatan di hari pertama besar estimasi peluang ketahan hidupnya adalah $100 \%$ kemudian pada perawatan hari berikutnya sampai akhir pengamatan mengalami penurunan hingga $99,1 \%$ setelah terdapat 1 pasien yang meninggal pada waktu perawatan hari ke 2.

\section{SIMPULAN DAN SARAN}

Peluang ketahanan hidup pada penderita penyakit DBD dengan menggunakan metode Kaplan meier sebelum terdapat pasien meninggal adalah 100\%. Namun mengalami penurunan peluang ketahanan hidup sampai akhir pengamatan setelah terdapat 1 pasien yang meninggal selama pengamatan yaitu $99,1 \%$.

Adapun saran dari penelitian ini yaitu dikarenakan dalam melakukan pernaksiran ketahanan hidup dengan mengggunakan metode ini tidak menggambil keputusan yang sebenarnya hanya sebatas membuat penaksiran dengan demikian untuk peneliti selanjutnya disarankkan dapat menggunakan metode ini dalam kasus lain yang lebih berkaitan erat dalam kehidupan sehari-hari untuk membantu setiap orang dalam melakukan suatu 
penaksiran. Pemerintah juga perlu turut serta dalam pemberian informasi kepada masyarakat mengenai tanda dan gejala DBD serta, penanganan pertama pada penderita DBD.

\section{DAFTAR PUSTAKA}

[1] R. T. Yohanes, "Pengecekan Asumsi Proportional Hazard pada Model Cox PH," Skripsi, FMIPA Univ. Indones. Depok., p. 30, 2011.

[2] W. H. Wang et al., "Dengue hemorrhagic fever - A systemic literature review of current perspectives on pathogenesis, prevention and control," J. Microbiol. Immunol. Infect., vol. 53, no. 6, pp. 963-978, 2020, doi: 10.1016/j.jmii.2020.03.007.

[3] M. Muhajir and Y. D. Palupi, "Survival Analysis of Child Patient Diarrhea Using Kaplan Meier Method and Rank Log Test," J. Eksakta, vol. 18, no. 1, pp. 74-84, 2018, doi: 10.20885/eksakta.vol18.iss1.art8.

[4] D. Gayatri and E. Halley, "MENGENAL ANALISIS KETAHANAN ( SURVIVAL ANALYSIS )," vol. 9, no. 1, pp. 36-40, 2005.

[5] I. Fungsi et al., "Tatik Widiharih dan Nasichah Siska Andriani (Inferensi Fungsi Ketahanan dengan Metode Kaplan-Meier)."

[6] S. A, "Fakultas Kedokteran Universitas Lampung Demam Berdarah Dengue ( DBD ) Fakultas Kedokteran Universitas Lampung," Medula, vol. 2, no. 2, pp. 1-15, 2014.

[7] M. Hikmah and O. W. Kasmini H, "Faktor Yang Berhubungan Dengan Kejadian Kematian Akibat Demam Berdarah Dengue," Unnes J. Public Heal., vol. 4, no. 4, pp. 180-189, 2015, doi: 10.15294/ujph.v4i4.9693.

[8] R. Hidayat, "PENGGUNAAN METODE KAPLAN-MEIER DAN LIFE TABLE ANALISIS SURVIVAL UNTUK DATA TERSENSOR," vol. 07, no. 1, pp. 1-9, 2016.

[9] B. P. Statistik, Provinsi Sulawesi Selatan dalam Angka 2019. 1390.

[10] F. Panorama, "Analisis Survavival Penyakit Jantung Berulang," 2017.

[11] J. Harlan, Analisis Survival. 2017.

[12] Sugiyono, STATISTIK untuk PENELITIAN. 2010.

[13] T. G. Clark, M. J. Bradburn, S. B. Love, and D. G. Altman, "Survival Analysis Part I: Basic Concepts and First Analyses utorial Paper Survival Analysis Part I: Basic concepts and first analyses," no. May 2014, 2003, doi: 10.1038/sj.bjc.6601118.

[14] L. P. Hutahaean, M. A. Mukid, and T. Wuryandari, "Model Regresi Cox Proportional Hazards Pada Data Lama Studi Mahasiswa," Gaussian, vol. 3, no. 2, pp. 173-181, 2014.

[15] J. Kim, "Survival analysis," Pediatr. Rev., vol. 33, no. 4, pp. 172-174, 2012, doi: 10.1542/pir.33-4-172. 
[16] C. Paper, "Logistics of E-Groceries.de," Leibniz-Informationszentrum Wirtschaft Leibniz Inf. Cent. Econ., 2015.

[17] F. Rachman, S. Wahyuningsih, and Y. Novia, "Analisis Survival Lama Masa Pengobatan Dan Tingkat Kesembuhan Pasien Narkoba Di Lembaga Terapi Dan Rehabilitasi Pondok Pesantren Ibadurrahman Tenggarong Seberang ( Survival Analysis of The Long Term of Medical Treatment and Recovery Rates for Narcotics Pa," J. EKSPONENSIAL, vol. 7, pp. 41-50, 2016.

[18] H. Nopianto, "FAKTOR-FAKTOR YANG BERPENGARUH TERHADAP LAMA RAWAT INAP PADA PASIEN DEMAM BERDARAH DENGUE DI RSUP DR KARIADI SEMARANG," 2012.

[19] L. Handayani, M. Fatekurohman, and D. Anggraeni, "Survival Analysis in Patients with Dengue Hemorrhagic Fever (DHF) Using Cox Proportional Hazard Regression," Int. J. Adv. Eng. Res. Sci., vol. 4, no. 7, pp. 138-145, 2017, doi: 10.22161/ijaers.4.7.22. 